\title{
Case Study on an Alcoholic
}

\author{
Dr. Tinni Dutta \\ Lecturer, Department of Psychology, Asutosh College, Kolkata, India. \\ tinnid@yahoo.com
}

Case study refers to intensive investigation of case highlighting different dimension. In this present study the case was admitted in reputed de-addiction/rehabilitations center, Kolkata, India. This case study implies a retrospective archival approach. Case history was taken thoroughly and psychological tests were administered to corroborate findings with case history.

Amal was admitted in the centre with the chief complaints of consuming alcohol which hampers his physical, emotional, occupational and social life. The criteria for alcohol intoxication include drinking and significant maladaptive behavioural changes - such as inappropriate aggressive behaviour, mood labiality, impaired judgment in family and occupational spheres shortly after alcohol consumption. He denies of his problems and often becomes defensive. Detection of alcoholism in this particular case was done by CAGE Test.

C) Have you ever felt you should cut down on your drinking?

A) Have you felt Annoyed when criticized for drinking?

G) Have you ever felt guilty about your drinking?

E) Did you need a drink early in the morning Eye openers?

Dynamic analysis of CAGE test implied euphoric mood, gregariousness and inhibition. Medical treatment history reveals that alcohol affects neuronal cell wall fluidity and permeability. Release of dopamine in the mesolimbic system brings euphoria and inhibition of glutaminergic transmission mediates amnesic effects.

\section{TEST BEHAVIOUR}

Rapport was established with him. He was sober and co - operative during the testing session. He has expressed mood swings on and often.

\section{Test Administered}

Bender Gestalt Test (BG).

Draw a person Test (DAP).

Rorschach Ink Blot test (RIBT).

Thematic Apperception Test (TAT).

\section{Findings}

The score of 67 put him BG in the suspect category which signifies slight impairment in his visual motor gestalt functioning. Qualitative analysis reveals difficulty in maintaining adequate interpersonal relationship, social anxiety, aggressiveness and a withdrawal tendency.

Qualitative analysis of DAP reveals need for dependency, a regressive trend and a tendency to seek fantasy than rather than reality satisfaction.

RIBT test result reveals there is only piled up instinctual needs but he is totally helpless to do anything with 
Case Study on an Alcoholic

it successfully either by finding a socialized or by intellectual canalization. Only means of handling is by withdrawal.

TAT

The main problem stems from TAT is a strong aggressive desire which is becoming fused with most of his activities even pleasurable ones. The only way he is handling this is by projective aggression on others and on environment or to internalize. There is attempt to canalize aggression through achievements but failure to do resulting in preoccupation and fantasy activity.

\section{Impression}

The person is suffering from 'Psychoactive Substance Abuse Disorder' associated with secondary depression.

\section{THERAPEUTIC INTERVENTION}

\section{Daily Feelings Journal}

The person was instructed to write 'Daily Feelings Journal' highlighting on feelings not on incidents.

\section{Daily Thought Record}

\begin{tabular}{|l|l|l|}
\hline Situation & Negative Automatic Thoughts & Emotion \\
\hline $\begin{array}{l}\text { 'I have to check papers } \\
\text { related to business' }\end{array}$ & $\begin{array}{l}\text { My hand will shake while signing the paper } \\
\text { I should prefer 1 peg alcohol after finishing the job. }\end{array}$ & Anxiety \\
\hline
\end{tabular}

After 45 days - How are you feeling now?

Better, feeling control over emotion.

\section{CONCLUSION}

Considering case history, behaviour and findings of test it appears the person was suffering from 'Psychoactive Substance Abuse Disorder associated with secondary depression. He has undergone therapeutic intervention. Cognitive behaviour therapy was provided to him strengthen his mental equilibrium.

\section{REFERENCES}

1. Dryden, W K, Neenan M (2006) Cognitive therapy, SAGE - 49, 50, 51.

2. Gray. Zide (2008). Psychopathology A Competency - based Assessment Model for social workers Cengage learning 361, 362, 363.

3. Kaplan \& Sadock (2011). Study guide and self - Examination Review in psychiatry, Lippincott William \& Wilkins - 104

4. Sethi, S. (2008). Textbook of psychiatry CBS Publishers \& Distributions Pvt. Limited. - 48, 49.

5. Singh, A K (1996). Tests, Measurments and Research Methods in Behavioural Sciences, Bharati Bhawan. - 387.

Citation: Dr. Tinni Dutta. "Case Study on an Alcoholic". American Research Journal of Humanities and Social Sciences, vol 5, no. 1, 2019, pp. 1-6.

Copyright (C) 2019 Dr. Tinni Dutta, This is an open access article distributed under the Creative Commons Attribution License, which permits unrestricted use, distribution, and reproduction in any medium, provided the original work is properly cited. 